\title{
PECULIARITIES OF THE RELATED TYPE OF MOTIVATION AND ACADEMIC SUCCESS OF STUDENTS: CROSS-CULTURAL ASPECT
}

https://doi.org/10.37096/SHDISJ-20-1.1-0013

\author{
Zapeka Yana, \\ ORCID ID: 0000-0002-3412-3629 \\ Su Fey, \\ ORCID ID: 0000-0002-6772-0921 \\ Lilia Sirocha \\ ORCID ID: 0000-0003-1033-8075
}

\begin{abstract}
The purpose of the article is to present the results of the study of the relationship between the type of motivation of academic activity with the academic achievement of Ukrainian and Chinese students and identify cultural differences.

Research methodology. In order to find out the cultural characteristics of academic motivation and academic achievement of students, the sample included 30 Ukrainian and 30 Chinese students. We used the following diagnostic methods as: a questionnaire "Studying the motives of students' educational activity" (modified by A.O. Rean, V.O. Yakunin); a questionnaire «Diagnostics of students' educational activities by A.O. Rean, V.O. Yakunin» (in the modification of N.T.Badmayeva); a questionnaire « Learning the motivation of studying in higher educational institutions » (by T.I. Ilyina).

Results of the research. The received results show that there are differences in the indicators of the educational motivation of Ukrainian and Chinese students. Thus, unlike Chinese students, Ukrainians are more driven by external motives (getting a diploma), while Chinese students - with internal and gnostic motives (acquiring knowledge, mastering the profession). According to the results of correlation analysis, we can say that the internal and cognitive motives of the educational activity (acquiring knowledge, mastering the profession) directly relates with the interest in the profession and satisfaction of the chosen professional career (professional motives, motives of creative self-realization, educational and cognitive motives, communicative and social motives). The average score of the exam session has a direct correlation with the motivation for creative self-realization.

Discussion. It is shown that since Ukrainian students, unlike Chinese, can be characterized by external motivation to study, it is necessary for educational socialization to focus on the formation and development of the student's personality and nurturing independence and mature, subjective, and active life position.
\end{abstract}

Keywords: motivation of academic activity, academic achievement, adolescence, cultural dimension, socialization of personality.

\section{Introduction}

The modern world is becoming increasingly global and can be characterized by such features as variability, uncertainty, and increased stress. A famous Israeli historian and futurologist Y. N. Harari predicts that in the coming decades, due to the increasing technological development of society and the algorithmization of a large number of 
processes, the role of man in various professional fields will be radically reconsidered (Harari, 2018). Moreover, due to the emergence of some professions and the disappearance of others, a person will be forced to adapt to such changes. The Russian specialist in the field of personality psychology O.G. Asmolov, continuing this view, points out that now it is worth talking not about the process of human adaptation to changes, but rather about the process of "pre-adaptation". This process is an individual's ability to foresee changes and be ready for future events (Asmolov, 2015). According to the authoritative Ukrainian researcher in the field of developmental and pedagogical psychology O.I. Vlasova, in modern education there has already been a transition from the paradigm of knowledge to the paradigm of competence. According to the competency approach, the criterion for the success of learning is mastering competencies. We mean that it is the students' ability to apply knowledge and skills in practice. And one of the main tasks of modern institutions of higher education is the formation of students' competence of self-education, without which successful educational and professional activity is impossible (Vlasova, 2015). This task arises as a practical necessity, taking into account the fact of the credit-module system of education. According to this system, most of the study material the student has to study and master independently. These conditions are fixed in many documents that regulate the requirements for the organization of the current educational process. In this regard, it is necessary to point out the relevance of the thesis of lifelong learning. It is necessary to form the students' readiness to design and implement their own trajectory of educational activities throughout their professional careers All these will ensure the success of the individual in social and professional life.

At the macro level, educational institutions and other cultural and social institutions provide the process of socialization of the individual, entry of a young person into the world of culture, learning of patterns of behavior in society, systems of roles, and social statuses. Nowadays either education or personality experiences the active influence of information technologies (Internet, virtual reality, media, social networks, etc.) and change of vectors in the values of the individual. As an example, we can point out characteristic differences according to the theory of three generations $(\mathrm{x}, \mathrm{y}, \mathrm{z})$. This escalates the problem of communication between generations in the field of education, which turns out in topical issues that are often discussed in modern forums and conferences: "What to teach?", "What will be useful and necessary in the future?", "How to teach?" However, let's not forget that a very important role in academic success is played by the student's attitude to the learning process and knowledge, his interest in learning and his conscious need to acquire knowledge. Therefore, an important and urgent task of higher education is the formation and development of students' positive motivation for learning. Therefore, the aim of our research is to study the relationship between the type of motivation and academic success and finding out the impact of cultural characteristics on the learning process of the individual, using the example of Ukrainian and Chinese students. 


\section{Theoretical framework}

Many studies of domestic and foreign scientists are devoted to the problem of the success of the educational activity of students. One of the main determinants of success is the activity of the individual in achieving the goal. We mean that learning is not possible without a conscious goal to acquire certain knowledge, skills, and abilities. In the activity of learning a person reproduces not only knowledge and skills, but also the ability to learn, that is the ability to selfdevelopment as a subject of life. Therefore, the result of successful learning is also a positive dynamic of the personal development of the user of educational services. In educational activity, not only cognitive functions are combined, but also the needs, motives, emotions, and will of the learner. Studies of psychological and pedagogical aspects of student activity conducted by V.O. Yakunin indicate that the level of educational activity does not yet determine the student's academic achievements. According to the scientist's point of view, such core characteristics as intelligence and motivational orientation of the personality play a bigger role in the academic success (Yakunin, 1998) The impact of abilities on academic performance is not so simple, because a lot of depends from what exact place specific abilities occupy in the personality structure of a particular student, in the system of his life values. However, the author considers the connection between the academic success of students and special abilities, which are crucial for the development of professionally important qualities, to be unambiguous. The educational activity of students differs in its professional orientation and, accordingly, it differs with its increasing importance of professional motives for self-education.

So, it is obvious that a certain level of cognitive abilities and individualtypological features of the student can contribute to the effective acquisition of competencies. But, in many cases not only cognitive abilities and level of intelligence are important for successful learning, but mostly personal, motivational, and value characteristics, which are responsible for their successful use (Gordeeva, Osin, 2012).

In the process of receiving the higher education, the psychological basis of professional activity is formed. Therefore, a very important role in the formation of the individual as a professional has the period of entering into educational and professional activities. Motivation plays a significant role at this stage because the future study of the student depends on the motivation of the student to get a profession.

A motive - is the main driving force in the study of any educational subject. The human educational activity is carried out for it. Objects of the outside world, ideas, thoughts and experience, that is, what the need embodied - all these can be motives. Learning motivation is a complex and dynamic mental construct. It contains some components (meanings, motives, goals, interests) and it is manifested in a specific activity - learning. There are external and internal factors, which influence the motivational sphere of the student's personality. Internal psychological factors include: individual-typological features of personality, a potential of personality, its thirst for knowledge, a need for selfaffirmation and recognition, self-education skills, an achieved level of selfdevelopment, etc. And external 
"SOCIALIZATION \& HUMAN DEVELOPMENT" INTERNATIONAL JOURNAL

psychological factors include: the level of prestige, wages, the importance in the labor market, etc.

The structure of learning distinguishes the actual motives of learning and professional motives, which determine the direction of human activity and orientation in professional activities. Professional motivation is an internal driver of development and professionalism as a personal neoplasm and the individual as a whole. It provides the development of professional education and the culture of the individual.

According to A.A.Markova, in the process of receiving the higher education, learning motivation consists of two groups of motives - educational - professional and social. At the same time, until the end of students' study from the group of educational and professional motives should be formed motives of professional self-education. And from the group of social motives should be formed motives of professional cooperation (Markova, 1990).

Learning activity is always motivated by the fact that there are several sources of student activity - personal, internal and external. Personal sources of activity are interests, needs, attitudes, standards and stereotypes. All these determine the desire for self-realization and self-improvement. Internal sources of learning motivation include cognitive and social needs.

External sources of learning
motivation
include
requirements for compliance with social norms of behavior, communication and activities; and opportunities as objective conditions that are necessary for the development of educational activities. Different cultural peculiarities (western or eastern culture) also affect attitudes in the structure of personality and the selfconcept of students and their motivation (for example, the focus on success and high achievements is the feature of Western culture, which is embodied in the worldview of the individual). That is, the type of culture of the country affects human behavior, including his professional selfdetermination, and business activity.

In the context of discussing the research topic, it is necessary to consider the problem of learning motivation through the prism of the well-known typology of cultural dimensions by G. Hofstede. The system of personal values is formed in the process of socialization (in the family, schools, at work) and it differs in masculine and feminine cultures. The person's worldview begins to form in the family, and cultural stereotypes that are accepted in society are based. Hofstede's research shows that in masculine cultures children are taught ambition, contest, and a desire to become better, to succeed through their own efforts. Leaders and the best pupils, students are most valued in educational institutions (Reynolds, Valentine, 2014). On the contrary, in feminine cultures children are taught modesty, obedience, maintaining harmonious relationships with others, observance of moral and ethical norms of behavior. In schools, pupils and students do not try to be different from others, they do not strive to achieve high results because the main thing is to learn how to adapt to society and maintain good relations in the team.

The type of culture also influences which specialties students choose when they enter higher education institutions. In masculine countries, specialties are divided depending on what type of behavior is specific to a particular gender (women often choose pedagogy, and men - law and 
engineering). Students choose their future profession on the basis of future income or obvious benefits. In feminine countries, the social roles of men and women do not differ. Approximately the same number of men and women study in the same specialties. The choice of future profession is more influenced by interest in a particular subject, rather than by the desire for money (Reynolds, Valentine, 2014.).

\section{Research design and survey sample}

To study the peculiarities of the relationship between the type of motivation of educational activities with the academic success of students, we interviewed 60 students (30 Chinese students and 30 Ukrainian students), which formed two groups for comparison. We used the following diagnostic methods as: a questionnaire "Studying the motives of students' educational activity" (modified by A.O. Rean, V.O. Yakunin); a questionnaire «Diagnostics of students' educational activities by A.O. Rean, V.O. Yakunin» (in the modification of N.T.Badmayeva); a questionnaire «Learning the motivation of studying in higher educational institutions») (by T.I. Ilyina) (Karelin, 2007). In our study, we have also used a scale to evaluate one's satisfaction with academic success and indicators of the level of academic achievement in the form of the average score for the semester (based on selfreport).

We have used such quantitative methods of mathematical processing and data analysis with the use of a package of SPSS 17.0 as: k-means method, calculation of standard deviation and normal distribution, Spearman's correlation coefficient, Student's t-test.

\section{Results}

Analysis of the results of the questionnaire «Learning the motivation of studying in higher educational institutions» (by T.I. Ilyina) included a comparison of averages between groups of Ukrainian and Chinese students according to Student's ttest for independent samples. We found that the indicators on the scales "acquisition of knowledge", "mastery of the profession" and "getting a diploma" differ significantly (tabl.1).

Table 1. Comparative statistics of groups of Ukrainian and Chinese students according to the questionnaire

«Learning the motivation of studying in higher educational institutions » (by T.I. Ilyina)

\begin{tabular}{|l|l|c|c|c|}
\hline \multicolumn{1}{|c|}{ Scale } & \multicolumn{1}{|c|}{ Students } & N & Average value & $\begin{array}{c}\text { Standard } \\
\text { deviation }\end{array}$ \\
\hline \multirow{2}{*}{ Acquisition of knowledge } & Ukrainian & 30 & $8,7^{* *}$ & 1,618 \\
\cline { 2 - 5 } & Chinese & 30 & $10,5^{* *}$ & 1,661 \\
\hline \multirow{2}{*}{ Mastery of the profession } & Ukrainian & 30 & $5,8^{*}$ & 1,661 \\
\cline { 2 - 5 } & Chinese & 30 & $7,3^{*}$ & 3,161 \\
\hline \multirow{2}{*}{ Getting a diploma } & Ukrainian & 30 & $6,5^{*}$ & 3,161 \\
\cline { 2 - 5 } & Chinese & 30 & $8,0^{*}$ & 1,611 \\
\hline
\end{tabular}

$*$ - $\mathrm{p}<0,05, * *-\mathrm{p}<0,001$ (Student's t-test for independent samples)

Chinese students have higher scores on the scales of mastering the profession and acquiring knowledge, and Ukrainian students - on a diploma scale. This indicates a greater manifestation of curiosity, the desire to acquire professional knowledge and form important professional qualities among Chinese students during their education. If we are talking about Ukrainian students - the focus 
on formal receiving of the diploma is dominant.

Analysis of results of the questionnaire 'Diagnostics of students' educational activities by A.O. Rean, V.O. Yakunin" (in the modification of N.T.Badmayeva) also showed significant differences for groups of Chinese and Ukrainian students on the scales "communicative motives", "avoidance motives", "professional motives", "motives of creative self-realization", "educationalcognitive motives" and "social motives" (table 2).
Chinese students have higher scores on all scales except the "avoidance motives" scale. The data show that Chinese students are primarily guided by internal educational and cognitive motives, professional motives, and motives of creative self-realization as the leading motives of educational activities. In the second place, they have communicative and social motives. In Ukrainian students, on the other hand, the external motive for avoiding failure was more pronounced. No significant differences were found between the groups on the scale of "prestige motives".

Table 2. Comparative statistics of groups of Ukrainian and Chinese students according to the questionnaire "Diagnostics of students' educational activities by A. O. Rean, V. O. Yakunin" (in the modification of N. T. Badmayeva)

\begin{tabular}{|l|l|c|c|c|}
\hline \multicolumn{1}{|c|}{ Scale } & \multicolumn{1}{|c|}{ Students } & $\mathbf{N}$ & Average value & $\begin{array}{c}\text { Standard } \\
\text { deviation }\end{array}$ \\
\hline \multirow{2}{*}{ Communicative motives } & Ukrainian & 30 & $3,5^{*}$ & 0,809 \\
\cline { 2 - 5 } & Chinese & 30 & $3,9^{*}$ & 0,857 \\
\hline \multirow{2}{*}{ Avoidance motives } & Ukrainian & 30 & $3,3^{*}$ & 0,788 \\
\cline { 2 - 5 } & Chinese & 30 & $2,8^{*}$ & 0,866 \\
\hline \multirow{2}{*}{ Motives of prestige } & Ukrainian & 30 & 3,5 & 0,792 \\
\cline { 2 - 5 } & Chinese & 30 & 3,6 & 0,795 \\
\hline \multirow{2}{*}{ Professional motives } & Ukrainian & 30 & $4,0^{*}$ & 0,795 \\
\cline { 2 - 5 } & Chinese & 30 & $4,6^{*}$ & 0,818 \\
\hline \multirow{2}{*}{$\begin{array}{l}\text { Motives of creative self- } \\
\text { Eealization }\end{array}$} & Ukrainian & 30 & $3,8^{*}$ & 0,790 \\
\cline { 2 - 5 } Educational-cognitive motives & Chinese & 30 & $4,4^{*}$ & 0,813 \\
\cline { 2 - 5 } & Ukrainian & 30 & $4,0^{*}$ & 0,795 \\
\hline \multirow{2}{*}{ Social motives } & Chinese & 30 & $4,6^{*}$ & 0,790 \\
\cline { 2 - 5 } & Ukrainian & 30 & $3,8^{*}$ & 0,813 \\
\hline
\end{tabular}

$*$ - $\mathrm{p}<0,05, * *-\mathrm{p}<0,001$ (Student's t-test for independent samples)

Thus, the received results make it possible to state the difference in the indicators of educational motivation of Ukrainian and Chinese students. Thus, unlike Chinese students, Ukrainians are more guided by external motives, and Chinese students are guided by internal ones.

To determine the relationship between the learning motivation scales in the sample as a whole, we performed a correlation analysis using the Spearman correlation coefficient and a two-way significance criterion. It was found that the indicator of "knowledge acquisition" has a direct correlation with the scales of "mastery of the profession" ( $\mathrm{r}=0.712$; $\mathrm{p} \leq 0.01$ ), "communicative motives" $(\mathrm{r}=$ $0.630 ; p \leq 0.01$ ), "professional motives" ( $r$ $=0.633 ; \mathrm{p} \leq 0.01)$, "social motives" $(\mathrm{r}=$ $0.633 ; p \leq 0.01)$, "motives of creative selfrealization" $(\mathrm{r}=0.633 ; \mathrm{p} \leq 0.01)$ and 
"educational-cognitive motives" $(\mathrm{r}=0.633$; $\mathrm{p} \leq 0.01)$. On the contrary, the indicator "knowledge acquisition" has an inverse correlation with the indicators of "getting a diploma" $(\mathrm{r}=-0.608 ; \mathrm{p} \leq 0.01)$ and "avoidance motives" $(\mathrm{r}=-0.637 ; \mathrm{p} \leq 0.01)$. Therefore, the thirst for knowledge and curiosity are directly related to the development of internal learning motives.

The indicator "mastery of the profession" has a direct correlation with the scales "communicative motives" $(\mathrm{r}=$ 0.684; $\mathrm{p} \leq 0.01)$, "professional motives" ( $\mathrm{r}$ $=0.736 ; \mathrm{p} \leq 0.01)$, "motives of creative self-realization" $(\mathrm{r}=0.736 ; \mathrm{p} \leq 0.01)$, "educational-cognitive motives" $(\mathrm{r}=0.736$; $\mathrm{p} \leq 0.01)$ and "social motives" $(\mathrm{r}=0.736$; $\mathrm{p} \leq 0.01)$. On the contrary, the indicator "mastery of the profession" has an inverse correlation with the indicators of "getting diploma" $(\mathrm{r}=-0.685 ; \mathrm{p} \leq 0.01)$ and "motives for avoiding failure" $(\mathrm{r}=-0.716$; $\mathrm{p} \leq 0.01)$. The received correlations confirm that the internal motives of educational activity are directly interrelated with interest in the profession and satisfaction with the chosen professional path.

The indicator "getting a diploma" has a direct correlation only with the "motive to avoid failure" ( $\mathrm{r}=0.810$; $\mathrm{p} \leq 0.01)$. On the contrary, the indicator "mastery of the profession" has an inverse correlation with the scales "social motives" $(\mathrm{r}=-0.811 ; \mathrm{p} \leq 0.01)$, "educational and cognitive motives" $(\mathrm{r}=0.811 ; \mathrm{p} \leq 0.01)$, "professional motives"( $\mathrm{r}=-0.811$; $\mathrm{p} \leq 0.01)$ and "communicative motives "( $\mathrm{r}$ $=0.794 ; \mathrm{p} \leq 0.01)$. These correlations indicate that those students who are more driven by external motives that are related to a formal attitude to the profession, they are guided not by motives of professional development, but they rather try to avoid failure. They focus on the assessment of others and follow the way of least resistance.

The average score of the creditexamination session has an inverse correlation with the motivation to avoid failures, and vice versa has a direct correlation with the motivation of creative self-realization. This may indicate that the motives for creative self-realization are supported by the desire to devote more time to their work and to develop as a professional, and the desire of selfimprovement, which has a positive effect on academic success.

The results of comparing the averages between the groups of Ukrainian and Chinese students showed that, while for Chinese students the focus is on "acquiring knowledge", Ukrainian students are more focused on "getting a diploma". This is confirmed by the distribution of motives by the questionnaire "Studying the motives of students' educational activity" (modified by A.O. Rean, V.O. Yakunin); where students were offered 16 motives, and they had to evaluate each of them on the basis of significance from 1 to 7 points. The results were processed by determining the frequency of mentioning the motives as the most significant in the whole sample. Based on the received results, the rank of the motive was determined. This allowed us to build a hierarchy of motives for Chinese and Ukrainian students. The five most important learning motives in each group were selected for analysis.

Ukrainian students consider such motives as more priority as: to successfully study, continue their study and fulfill pedagogical requirements, not to be worse than their classmates, to get approval from parents and others. The nature of these motives is more focused on the process of 
activity in the short term and the dominance of external motives.

Chinese students have shown a greater focus on the desire to become a highly qualified specialist; they want to get intellectual pleasure, they have a desire to gain the respect of teachers, successfully study and receive a diploma. Therefore that indicates the dominance of internal, more mature professional motives for learning, focus on long-term results, focus on the work in the specialty, social utility, and development of professional competencies. It can be assumed that Chinese students are more aware of why they need knowledge and how they will be able to use it in the future.

We also compared the average scores of the methods used according to gender. It is interesting that the leading motive for the group of men was "mastering the profession". And if we compare the women group - the motives of "getting a diploma" and "acquiring knowledge" were more dominant. This combination of motives may indicate either about satisfaction with the chosen profession or importance for part of the sample of formal consolidation of their status in society. That can mean the importance of higher education.

\section{Discussion}

The results of our study indicate differences in the cultural profiles of learning motivation of Chinese and Ukrainian students and the relationship of motive to creative self-realization with academic success. These results in some way complement the data of the research by L.V. Bondar, in which it is stated that external motives of educational activity really matter for students with low and medium levels of educational motivation. These external motives are namely the approval of parents, teachers, diplomas, and communicative motives. Also, according to L.V. Bondar, senior students are more willing to work in the specialty and to produce public benefits and acquire professional competencies. According to our study, this is typically only for Chinese students. So, we can assume that Ukrainian students will also have this motivation, but in later courses (Bondar, 2017).

Besides, the results of our study confirm the data of a sociological study by R.K. Malinauskas, which was on a sample of students of Lithuanian pedagogical educational institutions. Such motives as "the desire to expand horizons and erudition" and "the need for constant intellectual development" dominate among the motives for the development of personality. But at the same time, these motives do not differ between junior and senior students. The motives of "selfeducation" and "orientation to new knowledge" prevail among the cognitive motives. This indicates that students of different courses realize the need to study during their lives. According to social motives, the differences between junior and senior students are only based on such motives as "awareness of the need for higher education." This can be explained by the fact that senior students have a better understanding of the needs of the market in specialists. Junior and senior students have internal motivation as the dominating in the structure of motivation. In the second position, fourth-year students have an external positive motivation. The first-year students have an external negative motivation as the most dominant, particularly, the desire to avoid critics from teachers and friends, avoidance of possible punishments, and troubles (Malinauskas, 2005). Therefore, this corresponds to the 
data of our research, namely the results of a sample of Ukrainian students.

\section{Conclusion}

In our research, we have found significant differences in learning motivation among students from different cultures. Chinese students are primarily guided by the motives associated with the acquisition of knowledge and mastery of the profession, and Ukrainian students are guided by the motive for getting a diploma. This indicates a more mature learning position of Chinese students. We can assume, on the bases of the differences due to cultural and socio-economic conditions of development of countries, that such motivation of Chinese students is formed since school years. It can be due to high competitiveness, diligence, independence and earlier autonomy in relation to the parental family, because of the education in boarding schools. And a more superficial and formal attitude to learning and acquiring professional competencies among Ukrainian students can be explained by more bright crises of professional choice and separation from the parental family. The results of the study reveal that the predictor of academic success may be indicators of learning motivation, in particular, high rates of internal and cognitive motivation. The received results can be used in order to improve the quality of education in higher education institutions and to provide practical advice to curators, which will be useful in educational work with students. In the context of the data covered in the article, it may be promising to check for crosscultural differences at different stages of education of students of different specialties.

Conflict of interests: The authors declare no conflict of interest.

\section{References}

Asmolov A.G. (2015) Psikhologiya sovremennosti: vyzovy neopredelennosti, slozhnosti i raznoobraziya [The Psychology of Modernity: Challenges of Uncertainty, Complexity and Diversity] / A.G. Asmolov. Psikhologicheskiye issledovaniya (elektronnyy zhurnal) [Psychological research (electronic journal)] - T.8. \#40 [in Russian]

Vlasova O.I. (2015) Psykholohiia vyshchoi shkoly : pidruchnyk [Psychology of High school: a textbook] / O.I.Vlasova, V.A.Semychenko, S.Y.Pashchenko, Y.G.Nevidoma / za red. O.I.Vlasovoi. - K. : VPTs «Kyivskyi universytet» [PCP «Kyiv University»], 2015. - 405 p. [in Ukrainian]

Gordeeva T.O. (2012) Osobennosti motivatsii dostizheniya i uchebnoy motivatsii studentov, demonstriruyuschih raznyie tipyi akademicheskih dostizheniy (EGE, pobedyi $\mathrm{v}$ olimpiadah, akademicheskaya uspevaemost) [Features of achievement motivation and educational motivation of students demonstrating different types of academic achievements (USE, victories in olympiads, academic performance)] / T.O. Gordeeva, E.N.Osin.

Psihologicheskie issledovaniya. [Psychological research] - T.5. \#24. P.4. [in Russian]

Bondar L.V. (2017) Osoblyvosti motyvatsii navchalnoi diialnosti studentiv - maibutnikh praktychnykh psykholohiv [Features of motivation of educational activity of students - future practical 
psychologists] / L.V.Bondar. Visnyk Natsionalnoho aviatsiinoho universytetu. Seriia: Pedahohika, psykholohiia [Bulletin of the National Aviation University. Series: Pedagogy, Psychology], Vol. \#10. - 154 p. [in Ukrainian]

Harari Y.N. (2018) 21 urok dlya 21 stolittya [21 lessons for the 21st century] / Y. N. Harari - K.: Book Chef - 416 p. [in Ukrainian]

Karelin A.A. (2007) Bolshaya entsiklopediya psikhologicheskikh testov [Big Encyclopedia of Psychological Tests] / A.A. Karelin - M.: Eksmo - 409 p. [in Russian]

Malinauskas R.K. (2014) Motivatsiya studentov raznyih periodov obucheniya [Motivation of students of different periods of study] /
R.K.Malinauskas

Sotsiologicheskie issledovaniya [Sociological studies] - \#2. - P.134138 [in Russian]

Markova A.K. (1990) Formirovanie motivov ucheniya [The formation of motives for learning] / A.K. Markova, T.A.Matis, A.B.Orlov M.: Prosveschenie - 192 p. [in Russian]

Sana Reynolds, Deborah Valentine (2014). Guide to Cross-Cultural Communication, - $134 \mathrm{p}$.

Yakunin V.A. (1998) Pedagogicheskaya psikhologiya: Ucheb. posobiye/Evrop. in-t ekspertov [Educational Psychology: Textbook/ Europe. Institute of experts.] / V.A.Yakunin - SPb.: Izd-vo "Polius" $-639 \mathrm{p}$. 